\title{
Euclides da Cunha, Os Sertões e a invenção de um Brasil profundo
}

Ricardo de Oliveira

Doutorando Univerdidade Federal do Rio de Janeiro

\section{RESUMO}

Há um século nascia Os Sertões, verdadeiro monumento da cultura literária brasileira. Indissociável à própria idéia de Brasil, o livro foi considerado, ao longo desse período, como obra essencialmente nacional, a desvelar um Brasil profundo e autêntico. No entanto, poucas vezes se questionaram as conflituosas relações entre os conceitos de sertão e nação existentes no pensamento de Euclides da Cunha. Neste sentido, propomo-nos aqui a discutir esse problema, tomando como ponto de referência boa parte do corpus textual euclidiano. Procuramos compreender como o escritor, ao mesmo tempo em que constrói o mito da brasilidade sertaneja, vivencia-o de forma singularmente dramática.

Palavras-chave: Euclides da Cunha; Os Sertões; identidade nacional.

\section{ABSTRACT}

Os Sertões, a real monument of Brazilian culture, was published one hundred years ago. The book was considered as an essentially national text, discovering a deep and authentic Brazil. However, only a few times, the conflicting relations between Euclides da Cunha's concepts of hinterland and nation were questioned. Thus, I intend to discuss that problem based on "euclidiano" textual corpus. I will emphasize his elaboration of the myth of rustic "brasilidade" and his personal and dramatic experience. Keywords: Euclides da Cunha; Os Sertões; national identity.

"A colonização do Brasil fez-se da periferia para o centro: a sua nacionalização faz-se do centro para a periferia".

Olavo Bilac (1903)

Em 2002 celebra-se o primeiro centenário da publicação d'Os Sertões, e não haverá surpresa numa possível avalanche de comemorações que ultrapassará certamente os limites da comunidade acadêmica. Recordemo-nos que, não faz muito tempo, surgiu um suposto cânon da cultura literária brasileira em que, curiosamente, Os Sertões figura de forma unânime em primeiro lu- 
gar como o livro fundamental para a compreensão da formação histórica do País ${ }^{2}$. Neste sentido, segue-se uma tendência da crítica literária que durante esse século se debruçou sobre a obra euclidiana, desde as primeiras manifestações de recepção, compreendendo esta e seu autor como verdadeiros construtores da nação, justamente porque estes tratariam, como sintetizou Sílvio Romero, da verdadeira gente brasileira, isto é, os homens do sertão ${ }^{3}$.

Ao longo da ultima década, motivados talvez pela lembrança do centenário do massacre de Canudos, surgiram vários estudos em que, direta ou indiretamente, Euclides da Cunha foi revisitado, abrindo caminho para novas possibilidades interpretativas ${ }^{4}$. Mas, para além de todo debate formalista, de um lado, e sociológico, de outro, sobre Os Sertões, o que nos parece mais marcante é a estreita relação que se estabeleceu entre autor, obra e a própria idéia que fazemos acerca da brasilidade.

Em outra ocasião discutíamos como a cultura literária e científica durante a Primeira República construiu o mito da brasilidade sertaneja. Nesse processo, destacamos o lugar central que a obra, ou melhor, o que denominamos por momento euclidiano, ocupa no casamento das idéias de Brasil e Sertão como elementos simbólicos praticamente sinonímicos ${ }^{5}$. No entanto, permanecem pouco problematizadas essas relações. Notável ressalva, diga-se de passagem, para Berthold Zilly, responsável pela recente tradução para o alemão d'Os Sertões, que discute, no artigo "Sertão e Nacionalidade: Formação Étnica e Civilizatória no Brasil Segundo Euclides da Cunha”" algumas dimensões do conflito entre as idéias de sertão e nação no pensamento euclidiano. Nesse sentido, aproximamo-nos da discussão ensaiada por Zilly, mas pretendemos compreender a questão como estruturante à própria condição de possibilidade de se interpretar a obra e a trajetória de Euclides da Cunha no interior da cultura literária brasileira. E mais: imaginamos gigantescos os conflitos e tensões que subjazem ao casamento do sertão com a nação no interior não só da narrativa tortuosa d'Os Sertões, mas fundamentalmente no pensamento euclidiano.

Sabe-se que a visão de mundo do homem que chegou no alto-sertão da Bahia, com a incumbência de noticiar para um periódico sulista os derradeiros momentos do massacre dos sertanejos de Antonio Conselheiro, estava profundamente mergulhada nos pressupostos e preconceitos advindos do credo cientificista, isto é: evolucionismo, determinismos climático e biológico e, de uma forma mais geral, do positivismo. Por esse caminho, o conceito de sertão era compreendido da forma mais pejorativa possível, desqualificando a terra e a humanidade a ela relacionada, reconhecendo neles a impossibilidade de qualquer desenvolvimento rumo à civilização. Euclides, como boa parte dos intelectuais contemporâneos, compartilhava destas ferramentas mentais que possibilitavam uma maior compreensão da realidade do País. O sertão era per- 
cebido como território da barbárie, tal como o conceberam, na primeira metade do século, a elite imperial e o olhar estrangeiro, marcadamente ilustrado. A idéia de sertão sintetizava a representação do outro indesejado e distante, símbolo daquilo que não se poderia conceber como nacional ${ }^{7}$.

A trajetória intelectual de Euclides da Cunha, desde as primeiras letras, é extremamente sinuosa e já foi traçada em suas linhas gerais pelos biógrafos. Não pretendemos fazê-lo novamente, apesar de ser algo bastante interessante, devido ao fato de possibilitar a sistematização acerca do processo de leitura, aceitação e distanciamento de Euclides em relação ao bando de idéia novas que invadiu o País a partir de 1870, como assinalou Sílvio Romero. Porém, a invocação deste itinerário interpretativo serve para aclarar o seguinte problema: imaginamos que as categorias sertão e nação, assim como também ciência, civilização e natureza, no interior do pensamento euclidiano, desde seus primórdios, assumiram significados conflitantes entre si, significados estes que reaparecerão ao longo da vida e da atividade intelectual de nosso grande escritor sempre de uma forma específica, por vezes contraditória. Neste sentido, é importante frisarmos o seguinte: as atividades intelectuais de Euclides, anteriores à construção d'Os Sertões, são diversas e variadas, com temáticas e preocupações amplas, mas mantendo como centro a questão da nacionalidade. Na grande maioria, são crônicas e estudos relativos à realidade do País, mas some-se a elas uma boa quantidade de poemas e cartas que revelam outras faces do autor. Neste conjunto de escritos, encontramos inúmeros fundamentos da visão de mundo de Euclides, indícios de toda uma perspectiva que atravessará sua existência de forma indelével. Poderemos perceber o nascimento e a afirmação de um verdadeiro defensor dos mais elevados ideais científicos e soldado da civilização, convivendo ao mesmo tempo com o sentimento de um Romantismo explícito, que vive nas profundezas de sua alma o sonho do sertão-refúgio. Em síntese podemos dizer que, ao mesmo tempo, conviveram desde o início o intelectual militante, o cientista, o político e o homem do sertão ${ }^{8}$.

Os intérpretes da vida literária do período têm acentuado ser Euclides, de fato, uma personalidade extremamente avessa ao cosmopolitismo e agitação da Belle Époque carioca, sendo esse um curioso contraste à personalidade de um intelectual tão aferrado defensor dos mais altos ideais do progresso e da civilização. Brito Broca dizia que "nessa época em que todo mundo delirava por Paris" , Euclides da Cunha colocava-se justamente em posição contrária ao padrão de sociabilidade mais vulgar dentre o meio intelectual da época - no pólo oposto em que se situavam, em sua maioria, os chamados boêmios, de um lado, e aqueles intelectuais da qualidade de um Coelho Neto, um Bilac e um Rui Barbosa. Todavia, lembremos que Euclides nunca esteve só nesta postura céptica ante alguns traços da modernidade. Lima Barreto, ape- 
sar de várias vezes ter sido relacionado com a boêmia literária, esteve sempre observando, com um olhar extremamente crítico, a realidade que o cercava ${ }^{10}$.

Todavia, a opção pelo sertão, convivendo com a crença na civilização e no progresso, tornava a consciência do homem angustiada e sombria, e projetava reflexões que não poderiam deixar de expressar tais tensões. Noutra ocasião discutimos que a imagem mítica do sertão, enquanto elemento de fundação de nacionalidade, imagem do paraíso terreal, berço da nação, reduto do homem primordial da brasilidade, foi inicialmente e de forma restrita uma construção discursiva da literatura romântica ${ }^{11}$. Em Euclides, tal sentimento sobreexistiu, aninhado com os mais elevados valores do cientificismo. Romântico, buscou um exílio da agitação urbana, uma fuga para a solidão, pois quis viver o tempo perdido. Bastante jovem, a percepção do sertão e da natureza reveste-se de nostalgia e contemplação, traço que aparece num de seus primeiros escritos, intitulado Em viagem, veiculado pelo jornal O Democrata, de abril de 1889 . Há aqui explicitamente a fala do jovem romântico, discursando exaltadamente sobre a bela e pura natureza, posicionando-se contrário às realizações da sociedade industrial que degradam o meio ambiente. Leiamos com atenção:

É majestoso o que nos rodeia - no seio dos espaços palpita coruscante o grande motor da vida, envolto na clâmide do dia, a natureza ergue-se brilhante e sonora sublime de canções, auroras e perfumes... A primavera cinge, do seio azul da mata, um colar de flores e um sol oblíquo, cálido, num beijo ígneo, ascende na fronte granítica das cordilheiras uma auréola de lampejos... por toda a parte da vida...; contudo uma idéia triste nubla-me este quadro grandioso - lançando para a frente o olhar, avisto ali, curva sinistra, entre o claro azul da floresta, a linha da locomotiva, como uma ruga fatal na fronte da natureza...

Uma ruga sim, sim!...Ah! Tachem-me muito embora de antiprogressista e anticivilizador; mas clamarei sempre e sempre: - o progresso envelhece a natureza, cada linha do trem de ferro é uma ruga e longe não vem o tempo em que ela, sem seiva, minada, morrerá! E a humanidade não será dos céus que há de partir o grande Basta (botem b grande) que ponha fim a essa comédia lacrimosa a que chama vida; mas sim de Londres; não finar-se-á o mundo ao rolar a última lágrima e sim ao queimar-se o último pedaço de carvão de pedra...

Tudo isto me revolta, me revolta vendo a cidade dominar a floresta, a sarjeta dominar a flor! $!^{12}$.

O pensamento de um jovem que, no vigor dos seus pouco mais de dezoito anos, clama contra o assalto do progresso e da industrialização sobre a natureza, contrasta por certo com o do escritor-cientista que duas décadas depois surgiria? 
Nesse momento, porém, o que se conclui é que o pensamento do jovem Euclides da Cunha ajusta-se perfeitamente ao que se discute sobre o Romantismo de raiz rousseauniana, tanto no que se refere à sua nostalgia da natureza, idealizando harmonia e paz com o mundo natural, mas também quanto ao tom declamatório, muito comum aos padrões estéticos do romantismo. Outros exemplos desse Euclides romântico podemos encontrar nas pequenas, poucas e esteticamente inconsistentes incursões que este fez pelo campo do lirismo. Aspecto curioso de sua criatividade literária, os poemas escritos por ele, que compreendem um período grande de tempo ${ }^{13}$ são um depoimento de uma consciência vivendo, de forma indelével, o sonho da idade do ouro. Vejamos, por exemplo, essa poesia, cujo tom e temática se aproximam muito daquilo que sustentamos. Composta em 1883 chama-se Eu quero.

Eu quero à doce luz dos vespertinos pálidos Lançar-me, apaixonado, entre as sombras das matas

Berços feitos de flor e de carvalhos cálidos

Onde a poesia dorme, aos cantos das cascatas...

Eu quero aí viver - o meu viver funéreo, Eu quero aí chorar - os tristes prantos meus...

E envolto o coração nas sombras do mistério, Sentir minh' alma erguer-se entre a floresta de Deus!

Eu quero, da ingazeira erguida aos galhos úmidos, Ouvir os cantos virgens da agreste patativa....

Da natureza eu quero, nos grandes seios úmidos Beber a Calma, o Bem, a Crença - ardente e altiva. Eu quero, eu quero ouvir o esbravejar das águas das asp'ras cachoeiras que irrompem do sertão... E a minh'alma, cansada do peso atroz das mágoas, Silene acometer no colo da so'idão $(. . .)^{14}$.

Esse poema, além da marca da juventude, nos remete imediatamente ao trecho transcrito há pouco, a imagem de uma paisagem sertaneja profundamente diferente da qual o mesmo Euclides mais tarde, n'Os Sertões, irá consolidar com os assustadores quadros da terra seca e da escassez de vida. Nesse poema, podemos perceber claramente a referência à percepção do conceito de sertão, sob os signos de uma paisagem bucólica e evasiva, algo bastante curioso para uma consciência que se formava nos quadros de ferro do credo cientificista. O mesmo poderá ser observado na poesia A cruz da Estrada, de 1884:

Se vagares um dia nos sertões,

Como hei vagado — pálido, dolente 
Em procura de Deus — da fé ardente

Em meio das soidões...

Se fores, como eu fui, lá onde a flor

Tem do perfume a alma inebriante,

Lá onde brilha mais que o diamante

A lágrima da dor...

Se sondares da selva a entranha fria

Aonde dos cipós na relva extensa

Noss'alma embala a crença.

Se nos sertões vagares algum dia...

Companheiro! Hás de vê-la.

Hás de sentir a dor que ela derrama

Tendo um mistério, aos pés, de um negro drama.

Tendo na fronte o raio de uma estrela!...

Que vezes a encontrei!... Medrando calma

A Deus, entre os espaços

No desgraçado, ali tombado, a alma

Que tirita, quem sabe?, entre os seus braços.

Se a onça vê, lhe oculta a asp'ra ferrenha

Garra, estremece, pára, fita-a, roja-se,

Recua trêmula e fascinada arroja-se,

Entre as sombras da brenha...

E a noite, a treva, quando aos céus ascende

E acorda lá a luz,

Sobre os seus braços frios, nus,

Tecido de astros em brial estende...

Nos gélidos lugares

Em que ela se ergue, nunca o raio estala,

Nem pragueja o tufão... Hás de encontrá-la

Se acaso um dia nos sertões vagares $(. . .)^{15}$.

No entanto, havia também a negação do sertão no âmbito da sua concepção do que era a nacionalidade. Como falamos, o repórter que chegou ao arraial do Belo Monte não diferia aparentemente em nada dos outros que, como ele, narravam para a gente civilizada do litoral a vitória da República contra o atraso, a doença e a barbárie. A concepção de nação que tinha então Euclides alinhava-se à noção de nação republicana, largamente propagandeada nos primeiros tempos de implantação do regime. Por essa via, a idéia de nação materializou-se na construção do regime republicano e com a invenção de um imaginário apropriado à nova ordem que se diferenciava da velha, 
corroborando para o esquecimento dos símbolos ligados à monarquia ${ }^{16}$. Isto é explícito nessa anotação da Caderneta de Campo:

A saudade, imensa e indefinível dos entes queridos ausentes, desce às vezes profunda e dolorosa - esmagadora. Ao mesmo tempo, porém, como um antídoto infalível alevanta-se iluminando ao norte o nosso grande ideal - A República — profundamente consolador e forte, amparando vigorosamente os que cedem às mágoas, impelindo-os à linha reta nobilitadora do dever.(...) Eu nunca pensei que esta noção abstrata da Pátria fosse tão ampla...

Compreendo-o agora. Em breve pisaremos o solo onde a república vai dar com segurança o último embate aos que a pertubam. Além, para as bandas do poente, em contraste com o dia que nos rodeia fulguramente, alevantam-se por acaso agora cúmulos pesados traduzindo fisicamente uma situação social tempestuosa. Surgem, alevantam-se justamente neste momento do lado dos sertões, pesados lúgubres — ameaçadores.

(...)

Que a nossa Vendéia se envolva num largo manto tenebroso de nuvens, avultando além em contraste com os deslumbramentos do grande dia tropical que nos alenta com a sombra de uma emboscada; rompê-la-emos em breve com as fulgurações da metralha e o cintilar vivíssimo de espadas.

E domá-la-emos — a República é imortal (... $)^{17}$.

Em correspondência de 20 de agosto de 1897, pouco menos de dois meses do terrível desfecho da guerra, chama Canudos de Arraial Maldito ${ }^{18}$; e não cansava, nos dois artigos A Nossa Vendéia que enviou para O Estado de S. Paulo, publicados a 14 e 17 de julho, de lamentar a barbárie dos sertanejos e exaltar o heroísmo dos soldados da República.

Sem sombra de dúvida, ecoava nesse momento no pensamento de Euclides um clima de devoção à nação republicana, lutando contra a monstruosa ameaça do núcleo monarquista dos fanáticos sertanejos. Sabe-se, porém, que a imagem de Canudos, esse monstro terrível foi na verdade uma construção feita e alardeada através da imprensa das capitais litorâneas, principalmente a partir da pregação dos devotos jacobinos. Raoul Girardet expôs perfeitamente o poder das mitologias políticas que atuam no plano do alarde conspiratório, em que imagens e informações são construídas e manipuladas por grupos interessados no controle do imaginário ${ }^{19}$. $\mathrm{O}$ arraial do Conselheiro seria a tradução da barbárie, a perfeita encarnação do mal. Neste sentido, o pensamento de Euclides se alinha com a idéia de sertão que se tinha naquele momento ao nível do senso comum. Daí, portanto, a importância de Euclides da Cunha, pois seu livro é, acima de tudo, profundo exame de cons- 
ciência, não só individual, mas possivelmente coletiva. Walnice Nogueira Galvão, comentando a imagem com que através de Canudos o sertanejo foi projetado pela elite, observou:

Literatos ou cientistas, monarquistas ou republicanos, liberais declarados ou indiferentes, na verdade essas distinções são superficiais: todos os intelectuais estavam atrelados ao carro do poder, empenhados na grande parada histórica do tempo que era a consolidação nacional. Para fazê-lo, foi preciso usar ferro e fogo, o que repugnou a alguns; mas a repugnância veio depois do perigo ter sido afastado quando estava prestes a sê-lo. O acionamento dos métodos totalitários não é um dos princípios expressos na ideologia liberal; para extinguir a dissidência é sempre preciso violar alguns princípios. Surge daí a consciência dividida, de que Os Sertões é exemplar: para essa consciência, a meta histórica é boa mas os meios utilizados são maus. Como escapar ao dilema? Novamente, mediante a convivência intelectual por convicção ou omissão, e o lamento protestatório-humanitário depois do fato. Nem é preciso dizer que o fenômeno é recorrente, variando apenas a parada histórica em jogo. No caso, foi só nos momentos da Guerra ou depois de seu fim que os rebeldes começaram a ser chamados de brasileiros (...); até aí, a denominação comum é a de jagunçagem. E a incorporação à nacionalidade é o que pedem aqueles que protestam, já ou mais tarde, em nome dos sertanejos exterminados. Uma vez mortos, passam a ser irmãos ${ }^{20}$.

Portanto, não podemos afirmar, de forma alguma, que antes da experiência de Canudos, Euclides e a intelectualidade da época já haviam formalizado a mitologia da brasilidade sertaneja. No próprio pensamento euclidiano este processo - a convivência do sertão com a nação - era extremamente conflituoso, conforme se tentou apontar até aqui. Porém, do interior desta mesma cultura se erguerá uma outra imagem do sertão. Na linha de frente desta metamorfose encontramos Euclides da Cunha e seu livro, simbolizando o momento de maior tensão na inflexão sofrida no interior do imaginário.

Num país onde, de tempos em tempos, se tem a sensação da redescoberta, qualquer análise que se queira fazer sobre a sua realidade acabou, ao longo deste século, resvalando em Os Sertões. Neste percurso interpretativo, as polêmicas em torno da obra se avolumam por diversas vias, discutem-se desde as questões acerca do caráter ficcional, sociológico até jornalístico da obra. Essas polêmicas, diga-se de passagem, encontram-se já bastante saturadas. Decerto que a história das leituras do livro, por si só, é um objeto interessante. Havemos de concordar, pelo menos em parte, que muito da imagem que, hoje em dia, o País tem de si mesmo deve-se ao livro. Falar em sertão significa falar em brasilidade. No entanto, a discussão sobre as relações entre o objeto confesso do livro - o sertão - e a nação permaneceu escamoteada em 
virtude das questões possivelmente maiores, às quais os intérpretes preferiram se ater, já que, sendo a nação um dado, não se discute o caráter brasileiro da obra e do autor.

Procuramos apontar para alguns aspectos do percurso que as categorias sertão e nação tiveram no pensamento euclidiano nas épocas anteriores à construção d'Os Sertões e vimos que esta trajetória foi profundamente marcada por contradições e dilemas - fenômeno este que denuncia traço subjetivo marcante na personalidade conturbada do escritor, onde esses conflitos latentes em seu pensamento, de alguma maneira, estiveram presentes também por toda a sua vida. Euclides foi verdadeiro modelo de intelectualidade militante e crença nos poderes irreversíveis da civilização. Sua formação intelectual, baseada nos preceitos e crenças oriundos da visão de mundo cientificista, o dotava de um instrumental extremamente sofisticado à análise da realidade do País, bem como o levava também a buscar e encaminhar soluções e projetos. Ao mesmo tempo, pudemos perceber também que, convivendo com o cientista, havia o romântico a contemplar a natureza como se esta fosse a única possibilidade de redenção às dificuldades geradas pela vida moderna - romântico não só no plano simbólico, mas cuja produção lírica trazia à luz esta face de sua psique conflituosa. Portanto, imaginando e vivendo a idéia de sertão e de nação, estamos diante de alguém que carregou dentro de si o século XIX, sintetizando na sua alma ciência e fé, utopia e ceticismo. A partir do que se observou, nossa tarefa centrar-se-á na análise e interpretação desta questão no interior da narrativa d'Os Sertões, para que então possamos conferir mais luz à compreensão do processo cultural de união dos conceitos sertão e nação.

Uma primeira e inevitável consideração sobre a narrativa d'Os Sertões diz respeito à evidência de que se encontra completamente mergulhada nos pressupostos do cientificismo. A estrutura do livro, aliás, foi montada, como bem discutiu Luciana Murari ${ }^{21}$, a partir do modelo de inteligibilidade fixado por Taine (raça, meio e momento), onde, a partir da disposição narrativa $a$ Terra, o Homem e a Luta pode-se perceber claramente a proximidade intertextual entre esses pressupostos científicos. Além disso, como algo mais claro, logo na Nota Preliminar podemos perceber, numa das passagens mais conhecidas do livro, a afirmação de sua crença no progresso, na civilização e na ciência do século XIX. O trecho recortado enuncia uma perspectiva essencialmente teleológica, fundamental à visão de mundo cientificista, onde se lê, com todas as letras, o seguinte:

A civilização avançará nos sertões impelida por essa implacável força motriz da história que Gumplowicz, maior do que Hobbes, lobrigou, num lance genial, no esmagamento inevitável das raças fracas pelas raças fortes ${ }^{22}$. 
Entretanto, apesar do conflito interno à estrutura do livro, nos três pontos em que a narrativa do livro está encadeada, percebemos tacitamente as construções imaginárias, inicialmente de uma espacialidade nacional, em seguida o estabelecimento de um tipo étnico que encarnasse a nação, o sertanejo, e enfim, no momento da luta, o conflito mais grave que é o reconhecimento de que, grosso modo, a República, elemento que até então simbolizava de alguma maneira a idéia de nacionalidade, na cabeça do jornalista Euclides da Cunha presente no ocaso da tragédia, acabou sendo o algoz dos que são os primevos e essenciais brasileiros.

A construção de uma espacialidade brasileira no cenário sertanejo, o sertão-deserto do Nordeste, foi um processo intelectual dos mais complexos, visto que, dentre outras coisas, incorria na necessidade de se superar o modelo de análise mesológica imposto, principalmente, a partir das obras T. Henry Buckle e Ratzel. Apesar da polêmica e de vários, tais como Sílvio Romero, não aceitarem por completo essas matrizes intelectuais, é sabido, por exemplo, a enorme influência que uma pequena passagem do livro História da Civilização na Inglaterra exerceu na mente de vários e importantes intelectuais do período abordado. Capistrano de Abreu, inclusive, confessou que a leitura deste livro fora essencial à sua formação intelectual e posterior interpretação da 520 História do Brasil ${ }^{23}$. Porém, o curioso é que estes autores, na sua esmagadora maioria, além de nunca terem pisado nas terras do novo mundo, falavam destas da forma mais pejorativa possível, despejando um discurso marcado por um conceito de civilização que jamais seria possível à inclusão da terra e do homem de cá nos trilhos do progresso. Buckle, após elogiar muito a suntuosidade da natureza existente no Brasil, repetindo falas como as de Buffon e Raynal - pesquisando em fontes como Gardner, Spix e Martius, Darwin, Southey, etc. -, colocou em grande aporia aqueles intelectuais brasileiros crentes no determinismo geográfico e climático, ao dizer que:

Tais são a efusão e abundância vitais que distinguem o Brasil entre todos os países do mundo. Porém, no meio desta pompa, deste esplendor da natureza, não há lugar para o homem. Fica reduzido à insignificância pela majestade que o cerca. Tão formidáveis são as forças que se opõem, que nunca pôde fazer-lhes frente, ou resistir à sua imensa pressão. Todo Brasil, apesar das grandes vantagens que parece possuir, tem permanecido sem a menor civilização. Seus habitantes são selvagens errantes, incapazes de combater os obstáculos que a própria natureza espalhou em seu caminho ${ }^{24}$.

Acreditar nesta sentença significava, seguramente, conviver com a angústia e desolação, por vezes patética, de que a civilização nunca medraria cá nes- 
tas terras - e, portanto, conceber a natureza brasílica e, a partir dela, a nação, com uma espacialidade própria e distinta, era tarefa das mais delicadas.

Por outro lado, a paisagem sertaneja projetada n'Os Sertões é, para além da nomeada terra ignota, uma construção simbólica pela qual temos o cenário do martírio e da subseqüente redenção. De certa forma, há nela a presença de um sentido profundamente bíblico implícito à sua maneira realista de descrevê-la. Tal como já falamos, o sertão imaginado na primeira parte do livro é, fundamentalmente, a terra da provação e do desafio: "o martírio do homem, ali, é o reflexo de tortura maior, mais ampla, abrangendo a economia geral a vida" ${ }^{25}$, diz o famoso fecho do primeiro capítulo. Mas o próprio processo de adjetivação conferido à natureza vista, imaginada e nomeada por sertão, é riquíssimo neste sentido. Vejamos alguns exemplos:

E por mais inexperto que seja o observador - ao deixar as respectivas majestosas, que se desdobram ao Sul, trocando-as pelos cenários emocionantes daquela natureza torturada, tem a impressão persistente de calcar o fundo recém-sublevado de um mar extinto, tendo ainda estereotipada naquelas camadas rígidas a agitação das ondas e das voragens $(\ldots)^{26}$.

Nesta outra passagem, a paisagem sertaneja é a própria projeção do martírio:

A terra desnuda tendo contrapostas, em permanente conflito, as capacidades emissiva e absorvente dos materiais que a formam, do mesmo passo armazena os ardores das soalheiras e deles se esgota, de improviso. Insola-se e enregela-se, em vinte e quatro horas. Fere-a o sol e ela absorve-lhe os raios, e multiplica-os e reflete-os, e refrata-os, num reverberar ofuscante: pelo topo dos cerros, pelo esbarrancado das encostas, incendeiam-se as acendalhas da sílica fraturada, rebrilhantes, numa trama vibrátil de centelhas; a atmosfera junto ao chão vibra num ondular vivíssimo de bocas de fornalha em que se pressente visível, no expandir das colunas aquecidas, a efervescência dos ares; e o dia, incomparável no fulgor, fulmina a natureza silenciosa, em cujo seio se abate, imóvel, na quietude de um longo espasmo, a gargalhada sem folhas da flora sucumbida ${ }^{27}$.

Mais do que nunca, a imagem do deserto bíblico pode ser percebida no sertão imaginado por Euclides, neste processo de invenção de uma paisagem nacional, substancialmente distinta das paisagens projetadas até então sob a pena dos escritores românticos, a impressão que se tem é a da completa lentidão e imobilidade temporal. Observemos outra passagem bastante ilustrativa:

Ajusta-se sobre os sertões o cautério das secas; esterilizam-se os ares urentes; em- 
pedra-se o chão, gretando, recrestado; ruge o Nordeste nos ermos; e, como um cilício dilacerador, a caatinga estende sobre a terra as ramagens de espinhos $(\ldots)^{28}$.

A partir do fenômeno Os Sertões, percebe-se a delimitação do conceito de sertão articulado essencialmente à Região Nordeste e, mais especificamente, notamos algo mais significativo que foi o processo de identificação básica da idéia de sertão com a simbologia referente ao deserto (uma espécie de completa desertificação no significado da palavra). Mas, embora a etimologia da palavra autorize perfeitamente esta identificação, cabe lembrar que isto gerou um processo de restrição semântica sobre o vocábulo. Por outro lado, não podemos deixar de negar que esta imagem do sertão, apesar das manipulações e da inércia das autoridades, com os anos passou a gerar no seio da sociedade brasileira uma inquietação, deixando bem claro onde o descompasso com a civilização é mais evidente.

Voltando ao livro, sinalizemos que no decorrer da parte intitulada $A \mathrm{Ter}$ $r a$, permanece o problema do olhar do descobridor observando uma descoberta, e por mais que Euclides quisesse se afastar desta postura, a condição de ser um intelectual amarrado às formas de conceber o País, predominantes no imaginário dos membros da intelectualidade litorânea, tornava impossível a realização de um movimento que transcendesse os preconceitos. O cientista, buscando soluções para os problemas que martirizavam a terra, via na ação humana, verdadeira fazedora de desertos, um problema. Pioneiro de certa postura ecologicamente correta, Euclides esboça um diagnóstico da situação dos sertões do Norte na intenção de propor saídas, sem dúvida já naquela época possíveis, devido aos grandes avanços técnicos. Neste ponto, sonhava com um sertão verde e exuberante, tal como chegou a esboçar em passagens singelas do livro.

Mas o cenário sertanejo é a realidade crua do sacrifício. Os "rudes patrícios que por ali se agitam" ${ }^{29}$, vivendo o esquecimento e o descaso imposto pela nação, sob as intempéries de clima abrasador aniquilando pouco a pouco a chance de civilização, representariam a grande pergunta a ser respondida: como uma gente como esta resistiu tanto ao poderio do exército? A resposta, apesar de já sugerida em alguns momentos na primeira parte do livro, vem no decorrer dos dois capítulos seguintes.

Em O Homem, acima de tudo, Euclides quis estabelecer a imagem do homem nacional. Sem dúvida, é esta a parte mais contraditória e complexa do livro. Primeiro porque, oriunda das conjecturas do primeiro capítulo, a questão do determinismo mesológico era o substrato analítico de onde parte a análise; em segundo lugar, porque agora entra em cena outro problema a ser superado pelo escritor, isto é, o problema do determinismo biológico, fruto das teses racialistas desenvolvidas e amplamente propagadas nessa época. 
Euclides parte da certeza - evidente, porém, interdita — de que não existia no País unidade de raça e que — lamentando! — "talvez, não a teremos nunca" ${ }^{30}$, pois, "não há um tipo antropológico brasileiro" ${ }^{31}$. Por esse caminho, e pensando nos matizes impostos pelas teses racialistas, a mestiçagem derivada desta constatação aumentaria o drama na cabeça de Euclides. País de mestiços nunca alcançará a civilização. Há um fecho emblemático a essa tese na singular passagem intitulada Um parêntesis irritante, devotamente assentada nos pressupostos do determinismo biológico.

A mistura de raças mui diversas é, na maioria dos casos, prejudicial. Ante as conclusões do evolucionismo, ainda quando reaja sobre o produto o influxo de uma raça superior, despontam vivíssimos estigmas da inferior. A mestiçagem extremada é um retrocesso ${ }^{32}$.

Todavia, nesse ponto ocorre que, ao realizar o mapeamento dos tipos de mestiços existentes no País, estabelece distinção qualitativamente fundamental, separando os mestiços do litoral e os do sertão, colocando-os sob ópticas diferentes, afirmando a superioridade do mestiço do sertão, se comparado ao existente no litoral. Notemos que há neste trecho d'Os Sertões gigantesco esforço de subverter as teses científicas que negavam qualquer possibilidade de avaliação positiva sobre o fenômeno do cruzamento de raças. Não nos esqueçamos de que a visão negativa sobre o mundo americano era já bastante antiga, mas no século XIX, calcada em depoimentos como os do casal Agassiz, ou de Artur de Gobineau, foi amplamente propalada pela intelectualidade da época. Como bem lembrou Lilia Moritz Schwarcz, estas referências sobre o Brasil causavam enorme desconforto à intelectualidade, quando da aplicação destas teorias raciais à realidade do contexto local ${ }^{33}$. E se a questão racial era um dos critérios, senão o mais importante, um dos mais significativos para se estabelecer a identidade nacional, foi realmente um trabalho intelectual bastante difícil superar a carga pejorativa imposta pelo olhar europeu sobre a questão racial.

Como dissemos, o mestiço do litoral - identificado fundamentalmente com o mulato, fruto do cruzamento entre brancos e negros - foi imaginado como este mestiço degenerado e fraco, e por esse motivo, inevitavelmente, fadado a desaparecer. Enquanto fruto de um processo histórico distinto, o ser híbrido formado sob o sol dos sertões interiores da terra adquirira, ao longo dos séculos, uma feição própria, distinta e positiva. Numa das passagens mais conhecidas do livro, encontramos as seguintes assertivas:

Porque ali ficaram, inteiramente divorciados do resto do Brasil e do mundo, murados a leste pela Serra Geral, tolhidos no ocidente pelos amplos campos gerais, que se desatam para o Piauí e que ainda hoje o sertanejo acredita sem fins. 
O meio atraía-os e guardava-os.

As estradas de um e outro lado da meridiana, impróprias à dispersão, facilitavam antes o entrelaçamento dos extremos do país. Ligavam-nos no espaço e no tempo. Estabelecendo no interior a contigüidade de povoamento, que faltava ainda em parte na costa, e surgindo entre os nortistas, que lutavam pela autonomia da pátria nascente, e os sulistas, que lhe alargavam a área, abastecendo-os por igual com as fartas boiadas que subiam para o vale do rio das Velhas ou desciam até as cabeceiras do Parnaíba, aquela rude sociedade, incompreendida e olvidada, era o cerne vigoroso da nossa nacionalidade.

(...)

Raça forte e antiga, de caracteres definidos e imutáveis mesmo nas maiores crises - quando a roupa de couro do vaqueiro se faz a armadura flexível do jagunço - oriunda de elementos convergentes de todos os pontos, porém diversa das demais deste país, ela é inegavelmente um expressivo exemplo do quanto importam as reações do meio. Expandindo-se pelos sertões limítrofes ou próximos, de Goiás, Piauí, Maranhão, Ceará e Pernambuco, tem um caráter de originalidade completa expresso mesmo nas fundações que erigiu ${ }^{34}$.

Há nesta colocação a presença de uma tese essencialista pela qual a compreensão do fenômeno da originalidade do sertanejo se expressa na função da possibilidade de surgimento de uma raça diferenciada das demais que, através do embate com o meio, fez-se forte, contrariando as teses raciais vigentes. Dirá mais à frente que "o sertanejo é antes de tudo um forte. Não tem o raquitismo exaustivo dos mestiços neurastênicos do litoral" ${ }^{35}$.

As descrições dos tipos sertanejos, com seus hábitos singulares, nos suscitam enxergar em Euclides a tentativa de, como um antropólogo, realizar a decodificação de uma cultura à outra. E mesmo as avaliações inevitavelmente céticas da religiosidade popular existente no sertão, não removeram no escritor a possibilidade de afirmar que nos sertões estavam os verdadeiros brasileiros, pelo menos em forma embrionária, carregando dentro de si a responsabilidade de fazer a nação. Por este motivo, ocorre verdadeira inflexão na forma pela qual Euclides até então via o problema da Rebelião de Canudos. Embora não muito claramente, este trecho coloca-se no sentido de desmitificar a imagem que a propaganda republicana fizera de Canudos:

Vivendo quatrocentos anos no litoral vastíssimo, em que pelejam reflexos da vida civilizada, tivemos de improviso, como herança inesperada, a República. Ascendemos, de chofre, arrebatados na caudal dos ideais modernos, deixando na penumbra secular em que jazem, no âmago do país, um terço de nossa gente. Iludidos por uma civilização de empréstimo; respingando, em faina cega de co- 
pistas, tudo o que de melhor existe nos códigos orgânicos de outras nações, tornamos, revolucionariamente, fugindo ao transigir mais ligeiro com as exigências da nossa própria nacionalidade, mais fundo o contraste entre o nosso modo de viver e o daqueles rudes patrícios mais estrangeiros nesta terra do que os imigrantes da Europa. Porque não no-los separa um mar, separam-no-los três séculos $(\ldots)^{36}$.

O sertão é o lugar do esquecimento ${ }^{37}$ e, por isso mesmo, onde a brasilidade se forjou protegida da degradação e estrangeirismo do litoral. Lá o Brasil é profundo, autêntico! A mitologia sertaneja emerge, portanto, como representação possível do "sonho rural, a arcádia, a terra, fonte redescoberta de toda verdade e de todo renascimento". Esta mitologia, segundo propôs Raoul Girardet, estrutura-se a partir da visão "em torno da qual ele é um passado exemplar, onde o contato imediato com a terra protege o homem da degradação do tempo, associa-o aos grandes ritmos da natureza, assegura-lhe as condições de uma vida autêntica, liberta de toda falsa aparência e de todo subterfúgio". Neste sentido, o sertanejo - por assim dizer, o homem do campo - é concebido como alguém que "conhece a exata medida do tempo, do qual cada gesto comporta uma plenitude de significação, e sabe por instinto o que pertence ao domínio das realidades essenciais" ${ }^{\prime 3}$.

Por isso, a partir da oposição estrutural entre campo e cidade, surge neste contexto perfeito exemplo de como estes significados de pureza e essencialidade ligaram-se ao conceito de sertão naquele período, enquanto as cidades do litoral eram imaginadas como sombrias e promíscuas, elementos que impossibilitavam a construção da brasilidade. Desta maneira, o esquecimento que o País impunha ao sertão fora, de certa forma, benéfico, pois gerou condições de que sob o sol sertanejo se forjasse uma gente original que, no imaginário de uma geração, passou a expressar a alma nacional.

No sertão o tempo corre de outra forma, com outro ritmo e dimensão. É um tempo imobilizado, o tempo das origens cosmogônicas e imemoriais da nação. Euclides fez explicitamente referência a esta perspectiva de temporalidade imóvel, ao escrever que no sertão:

Tem-se a sensação esmagadora de uma imobilidade do tempo.

A terra realiza a sua rotação eterna, os dias sucedem-se astronomicamente, mas mudam aqui. Parece que é o mesmo dia que se desdobra sobre nós - indefinido e sem horas - interrompido apenas pelas noites ardentes e tristes.

E quando o sol dardeja alto, ardentíssimo num céu vazio, tem-se a impressão estranha de um spleen mais cruel do que o que se deriva dos nevoeiros de Londres; spleen tropical feito da exaustão de um organismo e do tédio ocasionado por uma vida sem variantes ${ }^{39}$. 
Neste lugar houve a gestação do primeiro e puro brasileiro, aquele que, como Adão, foi a árvore progenitora de todos os outros homens. O sertão, curiosa e contraditoriamente, firma-se como terra perdida. Sua imagem desertificada transforma-o no lugar das provações e martírios mais profundos. E, portanto, além de ter gerado o primeiro brasileiro, gerou um ente quase sobrenatural, um homem sublime. Voltando ao que sinalizou Girardet acerca da estrutura desta mitologia, podemos dizer que o sertanejo passou a encarnar, portanto, o "sonho da limpidez, de comunhão, de efusão e de harmonia", revelado através do mito da idade do ouro. Um "sonho de permanência - de um tempo solidificado, cristalizado...", isto é, assim como na fábula do Capitão Gancho, o sertão é um mundo mágico — um "mundo onde os relógios estão parados" ${ }^{40}$.

A efeméride da guerra propriamente dita, apesar de ser a parte mais longa d'Os Sertões, apontam para o fato de que a civilização de empréstimo, como ele diz, cometeu um grande erro de avaliação e que a loucura e a barbárie, na verdade, existiram dos dois lados, como forças centrífugas a condenar toda aquela gente à morte. No substrato da narrativa persiste, porém, a contradição estrutural do livro que é a de, ao mesmo tempo em que adjetiva o sertanejo como cerne da nacionalidade, o cientista, preso aos grilhões de seu credo, em vários momentos não consegue escapar dos preconceitos.

Todavia, o que é mais significativo neste processo hermenêutico é que ele permaneceu em aberto e, por isso, possibilitando-nos inúmeras reavaliações. O certo é o seguinte: se pelo caminho da ciência do século XIX, Os Sertões encontra-se preso às amarras de uma visão de mundo marcada por avaliações negativas sobre a terra e o homem do Brasil, pelo caminho do simbolismo mítico, com um substrato essencialmente romântico mesmo não declarado, mas parte integrante do imaginário de sua geração, ele supera os preconceitos e institui novas interpretações às teorias cientificistas vulgarizadas na época. O sertanejo é forte porque conjuga na sua constituição histórica alguns fatores singulares: a reação ao meio arredio, a purificação existencial, resultado do martírio secular da terra e do isolamento de sua formação sócio-histórica e, o mais importante de tudo, encarna, de certa forma, como fruto de uma concepção romântica presente no livro, o estereótipo do bom selvagem rousseauniano. Os Sertões, mais do que um livro em si, é o melhor exemplo da consciência partida de uma geração na busca de sua identidade de povo e nação. Se em 1897 Euclides da Cunha chegou ao arraial de Canudos como mais um repórter, preso às visões civilizadas do litoral sobre o sertão, o confronto com a trágica realidade dilacerou internamente o escritor, transformando o livro em um manifesto a favor da memória dos heróicos seguidores do Conselheiro, afirmando a existência de uma brasilidade sertaneja, como algo essencial à formação histórica do Brasil. 
Não obstante, abandonando o corpus textual d'Os Sertões, e observando seu epistolário, outra importante fonte para o estudo de seu pensamento, assusta-nos visualizar alguém que esteve realmente marcado durante toda vida pelo signo da tristeza, da solidão, da angústia e do desencanto. A tragédia pessoal envolvendo seu casamento, cada vez mais vem sendo desnudada e humanizada na intenção de resgatar e rever-se a relação com sua mulher, Ana de Assis, como uma união marcada pela ausência dele e pela infelicidade dela. Inclusive, há uma legítima tentativa por parte da família de Ana de Assis em questionar mais seriamente a postura de esposo de Euclides, mostrando-o como alguém que não conseguiu ser feliz e dar felicidade à mulher — daí, justificando a traição.

No entanto, apesar deste tema ser bastante interessante, até porque em suas correspondências publicadas não encontramos qualquer indício maior de apego para com a mulher, denunciando um problema estrutural no relacionamento entre os dois, evitamos uma análise mais detida acerca dessa questão, pois o casamento que realmente faz sentido discutir aqui é outro, um casamento que Euclides manteve paralelamente, por toda a vida, com o Brasil. União que, no início de sua trajetória intelectual, foi marcada por um arraigado sentimento utópico de esperança e felicidade, mesmo sendo o regime republicano algumas vezes motivo de críticas. Num artigo publicado no $O$ Estado de S. Paulo, a 5 de abril de 1892, ele nos fala de um sonho:

Seguiremos para o século futuro, robustos e grandes; neste século, cuja deslumbrante grandeza escapa às mais ousadas deduções da sociologia, através das vitórias da ciência e da indústria, a pátria brasileira redimir-se-á; e obedecendo à grandeza do próprio destino assumirá a hegemonia das nações latinas...

Todo um século de inatividade será compensado em alguns anos de lutas civilizadoras - e um grande futuro será afinal absolvição para um passado estéril ${ }^{41}$.

As esperanças em um País melhor, civilizado, soberano e que trilhasse os rumos do progresso foi compartilhada por toda uma geração de intelectuais, militantes como ele por esta utopia. Mas Euclides da Cunha foi alguém que, muito além das contradições de seu pensamento, vivenciou o Brasil de forma radical, profunda e na mesma medida, porém, da maneira mais angustiante possível, talvez só encontrando paralelo na também polêmica personalidade de Lima Barreto ${ }^{42}$.

Intelectual obstinado, não encontrou a realização profissional e nem sequer financeira na profissão que, meio a contragosto, escolhera. Como engenheiro, Euclides foi para si mesmo um grande fracasso. Ao longo de sua vida, confessara inúmeras vezes seu descontentamento com a profissão que escolhera. Certa vez escreveu a seu amigo paulista, Reinaldo Porchat (1868-1953), 
que viria a ser o primeiro reitor da Universidade de São Paulo, lastimando "não ser médico — afinal", pois segundo acreditava, "havia de ser sempre um engenheiro medíocre" ${ }^{43}$. Além disso, a própria função de pedagogo, à qual recorreu Euclides objetivando ter certa estabilidade financeira, também, pelo que podemos imaginar, foi-lhe deveras um verdadeiro estorvo ${ }^{44}$; da mesma forma que a vida militar, iniciada ainda bem jovem, na Escola de Engenharia da Praia Vermelha, onde, como sabemos, recebeu a primeira catequese positivista a partir das aulas de Benjamin Constant, foi, com os anos, parecendolhe algo igualmente terrível. Em correspondência datada de 27 de março de 1895, endereçada de Campanha, Euclides confidencia-se novamente ao seu fiel amigo Porchat, e diz: "Considero-me incapaz para a vida militar, incapaz fisicamente porque moralmente creio-me incompatível de há muito com ela" ${ }^{45}$.

Ao contrário do que muitos podem pensar, este desânimo que Euclides confessa aos amigos mais íntimos não foi fato isolado de determinado momento de sua vida. Ele que, como pudemos analisar em momento anterior, foi um dos nossos grandes profetas do republicanismo, chegando ao arraial de Canudos, em 1897, dando vivas à República e coisas do gênero, e da mesma forma, nos anos imediatamente anteriores ao golpe de 15 de novembro posicionou-se tão engajadamente contra o regime monárquico, no decorrer da vida, e mais acentuadamente nos últimos anos, olhou para a política e para o País com um imenso desalento. Euclides que se dizia tendo uma "feição serena de filho" pela República, logo se desencantou com ela. A República que não foi, logo nos primeiros tempos da sua vigência histórica, mostrou-se ser algo que estava longe de realizar as promessas da propaganda que a ajudou derrubar o velho imperador.

As utopias de progresso e civilização que deveriam instaurar concomitantemente à democracia e à cidadania, dando corpo definitivo à nação, não se realizaram. As grandes questões sociais continuaram esquecidas. Ao lado de dois governos militares que se instauraram no começo da República, uma crise financeira sem precedentes na história do País minavam os cofres públicos, aumentando os índices de pobreza e indigência. O Rio de Janeiro, capital federal, enquanto ainda não se tornava clara a hegemonia oligárquica, continuava a ser depósito de uma inoperante burocracia de Estado, agora encantada com as novas possibilidades que o novo regime oferecia. A elite em geral, como que retrospectivamente continuava acreditando que vivia um idílio no mundo de uma civilização feita de improviso. E o povo, as enormes massas rurais e urbanas, permanecia completamente alijado da cena política, bem como, por assim dizer, de qualquer forma de cidadania real. Educação e saúde eram, como ainda o são, setores abandonados pelo poder público. Na verdade, a substituição do velho regime pelo novo, na prática, não significou nada para a grande maioria das pessoas. A República cada vez mais foi se 
estruturando como um espaço de poder das oligarquias rurais, principalmente as do Sudeste, onde mais tarde a realidade da ideologia do regime se cristalizou na fala de um dos presidentes, que dizia sem peso algum na consciência que "a questão operária era um caso de polícia”, desnudando a forma aristocrática com que o governo olhava a questão social ${ }^{46}$.

Esta definitivamente não era a República dos sonhos daqueles intelectuais envolvidos com a progenitura da bela jovem. Paulatinamente estes iriam se retirando da cena política, e muitos deles isolaram-se nas torres de marfim construídas por eles para amenizar a angústia. Mas outros não possuíam esta capacidade de abstinência. Estavam envolvidos por demais com a construção da brasilidade, com a busca da identidade nacional. E seria para eles, como foi, algo terrível o simples virar de costas para o cenário político. Euclides da Cunha, neste ponto, pode ser visto como o grande paradigma desse desencanto. Uma comprovação do precoce desalento que o escritor passou a nutrir com a situação evidencia-se na carta enviada ao pai, com data de 14 de junho de 1890, oito meses após a Proclamação da República, onde há o seguinte desabafo: "desconfio muito que entramos no desmoralizado regime da especulação mais desensofrida e que por aí se pensa em tudo, em tudo se cogita, menos na Pátria" ${ }^{47}$.

Dois anos depois, a 7 de junho, novamente ao amigo Porchat dirá que não falaria nada "acerca da política porque" era coisa que não enchia um só minuto de sua vida; repetindo ao mesmo mais tarde o seguinte:

Quanto à política ... não falemos mais nisto; afastei-me inteiramente de tal assunto - compreendi afinal que nesta terra a política é a ocupação cômoda dos desocupados e só tenho um arrependimento sincero e profundo na vida: o terme, embora fracamente, me preocupado algum tempo com tal coisa ${ }^{48}$.

Portanto, ao contrário do que se costuma afirmar, o ceticismo com que Euclides passou a encarar as questões do País remontam, na verdade, a tempos bem anteriores à sua marcante experiência nos sertões da Bahia como repórter da tragédia de Canudos e, muito mais ainda, da própria construção do livro. Estamos insistindo no caráter contraditório que a estrutura narrativa do livro possui naquilo que lhe é essencial, isto é, o problema da inserção do sertanejo no horizonte da nação. Vimos, inclusive, a indefinição inicial que se obtém da leitura do livro, se considerarmos o problema ideológico do cientificismo que é o fator condicionante da estrutura narrativa da obra. Porém, lá no livro, como na intimidade do autor, não faltam tensões e dúvidas, contradições e problemas para alguém que, como Euclides, viveu intensamente as questões de seu tempo. Por esse aspecto, ele realmente sofreu e sofreu muito, vendo os seus sonhos militantes de mocidade se desmoronando, um a um ${ }^{49}$. 
Em dezembro de 1901, mais ou menos na época em que dava fim à escritura d'Os Sertões, Euclides queixou-se enfaticamente a um outro grande amigo, Francisco Escobar:

Neste país não há mais vitórias... Derrota e esborrachamento em toda linha, de Cucuí à Lagoa dos Patos! Felizmente nas entrelinhas da tua carta vejo-te o mesmo - o mesmo fino psicológico, ligeiramente ferino e sutil, incapaz de se enlear nos fiapos das preocupações eleitorais. Ainda bem.

Porque afinal, és como eu, um dissidente. Dissentimos, antes da cisão, de tudo isto - e nenhum de nós se pode escravizar a uma bandeira, porque a nossa oposição tem motivos superiores aos considerados vulgares dos manifestozinhos que por aí expluem.

(...) E se como eu, pensas que somos desventurados numa farsa lastimavelmente triste; e julgar como eu julgo, que este país é organicamente inviável; e se, comigo chegaste - rigorosamente, como no final de um teorema - à conclusão desanimadora de que chamamos política a uma grande conspiração contra o caráter nacional - se tudo isto é exato, estamos ainda formados, juntos, na mesma linha avançada e superior dos cépticos que ao menos não terão desapontamentos e desilusões ${ }^{50}$.

Euclides ia vendo o tempo passar e as coisas gradativamente piorarem mais e mais. O sonho acabara e ele estava mergulhado num enorme pesadelo. Daí, para além do sentimento moralmente conservador, se sentia um velho ainda quando da pouca idade que tinha: um velho em plena mocidade de vinte e poucos anos ${ }^{51}$. Este sentimento de apatia e descontentamento, infelicidade e insatisfação com o mundo e com a realidade que o cercava vão se tornando mais e mais constantes. Isto se refletia no olhar sobre o processo de modernização que a cidade do Rio de Janeiro viveu, no final do século e principalmente no primeiro decênio do novo. Um exemplo muito interessante disto é o desânimo com que confessa a Domício da Gama sua postura crítica diante da chegada ao País da grande maravilha da modernidade capitalista: o automóvel.

A vida entre nós, como já te disse noutra carta, mudou. Há um delírio de automóveis, de carros, de corsos, de banquetes, de recepções, de conferências, que me perturba - ou que me atrapalha, no meu ursismo incurável. Dá vontade da gente representar a ridícula comédia da virtude, de Catão, saindo por estas ruas de sapatos rotos, camisa de fiapos e cabelos despenteados. Que saudades da antiga simplicidade brasileira $(\ldots)^{52}$. 
Noutra correspondência escrita quatro meses depois, em fevereiro de 1908, enviada a Francisco Escobar, permanecerá o mesmo tom pessimista embalado por um manto de saudosismo por uma época e estilo de vida que, aparentemente, estava deixando efetivamente de existir, a partir dos processos de modernização característicos da conflitante inserção do País na Belle Époque. Leiamos:

Verás o Rio. Admirarás os célebres melhoramentos. Fulminaremos juntos, o pioramento dos homens. Daremos pasto à nossa velha ironia ansiosa por enterrar-se nos cachaços gordos de alguns felizes malandros que andam por aí fonfonando desabaladamente, de automóvel, ameaçando atropelar-nos a nós outros, pobres altivos diabos que teimamos em andar nesta vida, dignamente, pelo nosso $\mathrm{pe}^{53}$.

Vemos, a toda luz, um homem avesso ao cosmopolitismo, onde o Brasil e a República, bem como quase todas as suas outras crenças, pareciam ruir completamente devido à força das circunstâncias. Poucos meses antes do trágico incidente que o vitimou de morte, lamentava e ao mesmo tempo buscava forças para reagir em carta dirigida a Oliveira Lima:

Estamos num período de estéreis e exclusivas preocupações políticas. Só se lêem - verdadeiramente - os entrelinhados do jornal, onde se desenha com maior fidelidade, neste momento histórico, a fisionomia real de nossa gente. Ninguém lê; ninguém escreve; ninguém pensa. A mofina literatura nacional traduz-se, naturalmente, numa vasta poliantéia, a 100 réis por linhas, de mofinas. De todo absorvidas no presente, às voltas com seus interessículos, estes homens, são descuidados do futuro, ainda menos curam do passado; (...). Entretanto, quero crer que ainda haverá meia dúzia de espíritos capazes do esforço heróico de um rompimento com tanta frivolidade. E entre eles me alinharei ${ }^{54}$.

Euclides se encontrava num beco sem saída. Sozinho, cada vez mais fechado em seu mundo de angústia e desencanto, não lhe restou outra saída senão olhar para os remansos que os sertões da terra poderiam possibilitar. É curioso, mas, além de ser um dos construtores da mítica do sertão, o escritor foi alguém que, durante a vida toda, convivendo com as certezas da ciência de seu tempo, conviveu também com o sonho de ir fixar-se no sertão, de se retirar - fugir da agitação urbana e ir para os ermos. Discutíamos pouco atrás alguns sentidos possíveis com que a idéia de sertão surgia no pensamento euclidiano desde os seus primórdios até a escritura do grande livro. Vimos, inclusive, que Euclides formulou boa parte de sua lírica, marcada por acentuado romantismo, imaginando um sertão idílico e pitoresco, bem longe do realismo que estrutura todo Os sertões. Todavia, nele convivem ao mesmo 
tempo o cientista e o poeta, o sonhador e o pessimista, o gigante e o anão. Em agosto de 1892, aos 26 anos de idade, escrevera a Reinaldo Porchat:

Passo agora uma existência soberanamente monótona, uma vida marcada a relógio, mecânica e automática, como de uma máquina, oscilando indefinidamente, sem variantes, de casa para a Escola e da Escola para a casa - (...) Acredito porém que isto durará, não dou para a vida sedentária, tenho alguma coisa de árabe - já vivo a idealizar uma vida mais movimentada, numa comissão qualquer arriscada, aí por esses sertões desertos e vastos da nossa terra, distraindome na convivência simples e feliz do bugre ${ }^{55}$.

Há aqui ainda a presença do Euclides militante, homem que de alguma forma queria trabalhar pela construção da Nação Republicana e se via em plenas condições de se embrenhar nos sertões e trabalhar pela pátria. Mais de uma década depois, durante sua viagem ao Amazonas, em missão diplomática, novamente, apesar de todo o ceticismo com que nesta época enxergava a situação, dará um depoimento do mesmo tipo. Considerava-se um bandeirante, um filho da roça, que se mostrou bastante animado antes de partir para os sertões da Amazônia, pois achava que seria possível levar adiante este ideal; porque, não "desejava a Europa, o Bulevar, os brilhos de uma posição", desejava "o sertão, a picada malograda, a vida afanosa e triste de pioneiro" 56 . E quando, pouco tempo depois, já se encontrava por lá, diria a outro correspondente:

Não te direi os dias que aqui passo, a aguardar o meu deserto, o meu deserto bravio e salvador onde pretendo entrar com os arremessos britânicos de um Levingstone e a desesperança italiana de um Lara, em busca de um capítulo novo no romance mal arranjado desta minha vida ${ }^{57}$.

Entramos, então, no derradeiro momento da trama. Ao final de sua vida, mesmo antes de conhecer o trágico desfecho da Piedade, Euclides anunciava no interior de seus sentimentos a morte do Brasil que tanto amara ao longo de toda a sua vida. Chegou mesmo a confessar para Oliveira Lima que "andam nesta terra tão ao nível das maiores mediocridades as mais altas posições, que fora, na verdade, ridículo o entristecer-me com o não conseguir o modesto lugar de professor de lógica" ${ }^{58}$. Nesse ponto, soam como uma espécie de crônica duma morte anunciada estas reflexões feitas por ele em 8 de agosto de 1909, seis dias antes da derradeira tragédia:

Estou na reserva desde os vinte anos, quadra em que me assaltou o pessimismo incurável com que vou atravessando esta existência no pior dos países do mun- 
do. Talvez não acredites: ando nas ruas desta aldeia de avenidas, com as nostalgias de um inglês smart perdido numa enorme aringa da África Central. Nostalgia e Revolta: tu não imaginas como andam propícios os tempos a todas as mediocridades. Estamos no período hilariante dos grandes homens pulhas, dos Pachecos empavesados e dos Acácios triunfantes. Nunca se berrou tão convictamente tanta asneira sob o sol! Na Câmara e no Largo São Francisco, os mirabeaux andam aos pontapés. Em cada esquina um O'Connel; em cada degrau de Secretaria um salvador das instituições e da pátria. Da noite para o dia surgem não sei quantos imortais... É asfixiante! A atmosfera moral é magnífica para os batráquios. Mas apaga o homem. Já [...] penso em romper a fundo com tudo isto: dois ou três artigos desabalados e rijos - tomando a frente de toda essa sujeira $[. .$.$] canalha com o meu rubro desassombro de caboclo sans peur et sans$ reproche. Mas contenho-me $(. . .)^{59}$.

Euclides foi alguém que depositou todas as suas esperanças na razão e na ciência do século de Marx, Comte, Darwin e Spencer; e quis, com estas certezas, interceder e transformar a realidade do País, fazendo com que trilhasse o rumo do progresso e da civilização. Mas sabemos que seus sonhos e esperanças mais concretas se evaporaram como água em pleno ar. Para ele conviver com o fardo dessa derrota na consciência foi algo extremamente dramático. O grande filósofo e historiador das religiões Mircea Eliade, numa passagem extremamente feliz, afirmou que "um homem exclusivamente racional é uma abstração; jamais o encontramos na realidade" ${ }^{60}$, pois a experiência humana está mergulhada num universo de sonhos, mistérios e simbolismos ${ }^{61}$ onde a fronteira entre o racional e o irracional pode ser muito mais tênue do que pensa a filosofia ocidental. De certa maneira, cabe a menção à crítica filosófica que Albert Camus fez à ciência moderna em Le Mythe de Sisyphe, onde diz que "toda ciência desta terra não me dará nada que possa assegurar-me que este mundo é meu" ${ }^{62}$. Euclides da Cunha, a quem devemos celebrar sempre pela obra e pelo exemplo de empenho em encontrar soluções que conduzam a um país melhor, à sua maneira vivenciou intensamente o significado trágico desta sentença.

A angústia com sua vida e seu país tomavam conta da mente do escritor, e o homem só via tristeza nas situações que o cercavam. O casamento infeliz, a insatisfação com a profissão e as constantes dificuldades financeiras que, não poucas vezes, o forçavam a trabalhar a contragosto, tornavam para ele a vida um grande martírio. O sertão, o interior, o coração das terras — onde há calma, repouso e paz para o espírito — surgia à sua imaginação como a única possibilidade de felicidade e superação da condição de simples mortal. A nação que não era agravada em sua consciência de ex-mosqueteiro, o sentimento de derrota — que não foi só seu, diga-se de passagem, foi de toda 
uma geração. Mas ele, muito mais que qualquer outro, exilado na solidão de si mesmo, não teve outra saída senão sonhar com uma salvação, individual e, por vezes, coletiva, a esperá-lo lá onde o Brasil é profundo, nalguma vereda deste grande sertão.

\section{NOTAS}

${ }^{1}$ BILAC, Olavo. "Discurso em resposta à recepção de Afonso Arinos na Academia Brasileira de Letras, proferido em 18 de setembro de 1903". In Discursos Acadêmicos. Rio de Janeiro: Civilização Brasileira, 1934, p. 180.

${ }^{2}$ Revista Veja. Rio de Janeiro: Editora Abril, edição 1.367, n ${ }^{\circ}$ 47, 23 de novembro de 1994.

${ }^{3}$ Sílvio Romero afirmou o seguinte: "O que mais despertou, para logo, a atenção dos leitores foi o estilo imaginoso, brilhante, marchetado de metáforas do escritor, além do assunto, que parecia longínquo, exótico, inesperado à grande maioria dum público sofrivelmente ignorante, como o do Rio de Janeiro e do Brasil em geral. Aos espíritos mais sérios, porém, penso eu, manifestava-se, à primeira inspeção, o verdadeiro mérito do jovem autor: um grande talento formado fora do círculo das literatices da moda. Duas cousas o mostravam de pronto: a trama das idéias, onde se sentia o vinco de certas doutrinas sérias acerca de questões brasileiras, e o interesse pela genuína população nacional, a grande massa rural sertaneja, na qual palpita mais forte o coração da raça”. (ROMERO, Sílvio. História da Literatura Brasileira. Rio de Janeiro: José Olympio, Tomo V, 1954, p. 1941.)

${ }^{4}$ Referimo-nos basicamente aos seguintes trabalhos: LIMA, Luiz Costa. "Nos Sertões da Oculta Mímesis”. In O Controle do Imaginário. Razão e Imaginação nos tempos modernos. Rio de Janeiro: Forense Universitária, 1989, pp. 201-241. . Terra Ignota. A Construção de Os Sertões. Rio de Janeiro: Civilização Brasileira, 1997. ABREU, Regina. O Enigma de Os Sertões. Rio de Janeiro: Rocco: Funarte, 1998. LIMA, Nísia Trindade de. Um Sertão chamado Brasil: Intelectuais e a Representação Geográfica da Identidade Nacional. Rio de Janeiro: Revan: IUPERJ, UCAM, 1999./ LEVINE, Robert M. O Sertão Prometido: Massacre de Canudos no Nordeste Brasileiro. São Paulo: Edusp, 1995./ BERNUCCI, Leopoldo M. A Imitação dos Sentidos: Prógonos, Contemporâneos e Epígonos de Euclides da Cunha. São Paulo: EDUSP, 1995. / ZILLY, Berthold. "Sertão e Nacionalidade: Formação Étnica e Civilizatória no Brasil Segundo Euclides da Cunha”. In Estudos - Sociedade e Agricultura. Rio de Janeiro: UFRRJ/CPDA, $\mathrm{n}^{\circ}$ 12, abril de 1999. / , ALMEIDA, Ângela Mendes de, LIMA, Eli Napoleão de. (Orgs.). De Sertões, Desertos e Espaços Incivilizados. Rio de Janeiro: FAPERJ: MAUAD, 2001. História, Ciências, Saúde. Rio de Janeiro: Fundação Oswaldo Cruz, vol. 5, 1997.

${ }^{5}$ Em nossa dissertação de mestrado, Sertão e Nação: Euclides da Cunha e a Construção da Brasilidade Sertaneja, apresentada ao Programa de Pós-Graduação em História Social, UFRJ, Rio de Janeiro, 1998, discutimos de maneira ampla essa questão. Parte das nossas conclusões foram publicadas sob a forma de artigo. Ver: OLIVEIRA, Ricardo de. "Ficção, Ciência, História e a Invenção da Brasilidade Sertaneja". IPOTESI. Revista de Estudos Literários. Juiz de Fora: EDUFJF, vol. 4, jan-jun, 2000, pp. 37-53. 
${ }^{6}$ Ver: ZILLY, Berthold. Op. cit.

${ }^{7}$ Ver: OLIVEIRA, Ricardo de. Op. cit.

${ }^{8}$ Nicolau Sevcenko percebeu e sintetizou perfeitamente este traço fundamental na personalidade e obra de Euclides da Cunha, anotando que: "não deixa de ser fascinante o fenômeno da consciência dividida - tão típica da passagem do século - que vibra no cerne de sua obra. Romântico, do romantismo carregado e desabrido de Victor Hugo e Alfred Musset, ele estende seu culto ao determinismo mais obstinado, de Comte, Spencer e Gumplowicz. Seu espírito se identifica com os dois pontos extremos mais distantes do espectro cultural de sua época. Euclides da Cunha possui igualmente vivos em si, com o mesmo calor, exatamente os dois mundos que se negavam um ao outro, que só poderiam sobreexistir um à custa da morte do outro. Eram dois tempos, duas idades que se opunham pela própria raiz da sua identidade: o século XIX, literário, romântico e idealista; e o século XX, científico, naturalista e materialista”. (SEVCENKO, Nicolau. Literatura Como Missão. São Paulo: Brasiliense,1988, p. 133).

${ }^{9}$ BROCA, Brito. Vida Literária no Brasil-1900. Rio de Janeiro: José Olympio Editora, 1975, pp.99-101.

${ }^{10}$ Ver: SEVCENKO, Nicolau. Op. cit.

${ }^{11}$ Em nossa dissertação de mestrado, intitulada Sertão e Nação: Euclides da Cunha e a Construção da Brasilidade Sertaneja, anteriormente citada, desenvolvemos de forma mais ampla esta discussão, apontando para os limites da cultura letrada de natureza romântica em tratar a questão.

${ }^{12}$ CUNHA, Euclides da. “Em Viagem”. In: Obras Completas. Rio de Janeiro: Aguilar, vol. I, 1966, p. 517.

${ }^{13}$ De 1883 , quando este tinha apenas 17 anos, até 1905, quando já era reconhecidamente o consagrado escritor que mostrara o Brasil para o Brasil, encontramos poemas escritos por Euclides da Cunha.

${ }^{14}$ CUNHA, Euclides da. “Ondas e outros poemas Esparsos”. Op. cit., vol. I, p. 631.

${ }^{15}$ Idem, p. 637.

${ }^{16}$ Ver: CARVALHO, José Murilo de. Formação das Almas. O Imaginário da República no Brasil. São Paulo: Cia das Letras, 1995.

${ }^{17}$ CUNHA, Euclides da. Caderneta de Campo. São Paulo: Editora Cultrix, 1975, pp. 4-5.

18 _Carta a Reinaldo Porchat”. In Correspondência de Euclides da Cunha. São Paulo: Edusp, 1997, p. 108.

${ }^{19}$ GIRARDET, Raoul. Mitos e Mitologias Políticas. São Paulo: Cia das Letras, 1989, pp. 25-62.

${ }^{20}$ GALVÃO, Walnice Nogueira. No Calor da Hora. São Paulo: Ática, 1974, pp. 107-108.

${ }^{21}$ MURARI, Luciana. Brasil, ficção geográfica: ciência e nacionalidade n’Os sertões. Dissertação de Mestrado defendida no Programa de Pos-Graduação em História, da Faculdade de Filosofia e Ciências Humanas, Departamento de História, UFMG. Belo Horizonte: 1995, pp. 6-214. 
${ }^{22}$ CUNHA, Euclides da. “Os Sertões”. Op. cit., vol. II, p. 93.

${ }^{23}$ Ver: WEHLING, Arno. De Vanhargen a Capistrano. Historismo e Cientificismo na Construção do Conhecimento Histórico. Tese apresentada ao concurso de professor titular de Metodologia da História, IFCS/UFRJ. Rio de Janeiro, 1992.

${ }^{24}$ BUCKLE, Thomas Henry. História da Civilização na Inglaterra. São Paulo: Typografia da Casa Eclética, vol. I, 1900, p. 89.

${ }^{25}$ CUNHA, Euclides da. Op. cit., p. 136.

${ }^{26}$ Idem, p. 107.

${ }^{27}$ Idem, p. 112.

${ }^{28}$ Idem, p. 120.

${ }^{29}$ Idem, p. 115.

${ }^{30}$ Idem, p. 140.

${ }^{31}$ Idem, p. 153.

${ }^{32}$ Idem, p. 168.

${ }^{33}$ SCHWARCZ, Lilia Moritz. O Espetáculo das Raças. São Paulo: Cia das Letras, 1993, p. 36. ${ }^{34}$ CUNHA, Euclides da. Op. cit., p. 161.

$536 \quad{ }^{35} \mathrm{Idem}, \mathrm{p} .170$.

${ }^{36}$ Idem, p. 231.

${ }^{37}$ Dirá noutra passagem: “De sorte que sempre evitado, aquele sertão, até hoje desconhecido, ainda o será por muito tempo". Idem, p. 111.

${ }^{38}$ GIRARDET, Raoul. Op. cit., p. 113.

${ }^{39}$ CUNHA, Euclides da. Op. cit., p. 541.

${ }^{40}$ GIRARDET, Raoul. Op. cit., p. 129.

${ }^{41}$ CUNHA, Euclides da. "Crônica - Dia a Dia”. Op. cit., vol. I, p. 591.

${ }^{42}$ Ver: SEVCENKO, Nicolau. Op. cit.

${ }^{43}$ CUNHA, Euclides da. "Carta a Reinaldo Porchat, Rio de Janerio, 3 de setembro de 1892". Op. cit., p. 39. Em correspondência de Lorena, com data de 22 de março de 1903, escrita para Lúcio de Mendonça, ele retornará à temática do desgosto para com a profissão de engenheiro: "A minha engenharia rude, engenharia ardente, romanesca e estéril, levando-me em constantes viagens através de dilatado distrito, destrói a continuidade de quaisquer esforços na atividade dispersiva que impõe". Na mesma época dirá também a Araripe Júnior algo mais curioso ainda: "Eu creio que sairei breve desse desvio morto da engenharia, sem descarrilhar; aproveitarei o primeiro triângulo de reversão que aparecer, e avançarei na minha verdadeira estrada". São muito interessantes os depoimentos de Euclides, porque é algo bastante notório que a elite modernizadora tinha na engenharia um importante canal para alcançar na prática seus objetivos. 
${ }^{44} \mathrm{Na}$ mesma carta citada anteriormente, endereçada ao amigo Reinaldo Porchat, Euclides confessara-lhe o seguinte: "Continuo na missão inglória, na triste e monótona e profundamente insípida missão de pedagogo; já agora levarei essa cruz até o fim do ano. Entretanto, afirmam que dou às vezes boas lições”. Op. cit., p. 40. . “Carta a Reinaldo Porchat. Campanha, 27 de março de 1895”. Op. cit., p. 71.

${ }^{46}$ Ver: CARVALHO, José Murilo de. Os Bestializados. São Paulo: Cia das Letras, 1989.

${ }^{47}$ CUNHA, Euclides da. "Carta ao Pai - 14 de julho de 1890". Op. cit., p. 30. . “Carta a Reinaldo Porchat — 23 de maio de 1893". Op. cit., p. 49.

${ }^{49}$ __. “....) estupendos sonhos de mocidade (ó República) que não sei mais onde existem”. Op. cit., vol. II, p. 644.

${ }^{50}$ __ . “Carta a Francisco Escobar — 25 de dezembro de 1901”. Op. cit., p. 128.

${ }^{51}$ __. Escrevendo ao amigo Porchat, disse: "É mania, e mania antiga, esta de fantasiarme de velho e fingir-me coberto de cães e apresentar-me como um octogenário, duramente experimentado... será porque, nevropata como sou, tenho muito em poucos anos, ou porque nada tenho vivido e não sei o que verdadeiramente é a vida? A verdade é que eu me sinto mais velho do que moço...”. Op. cit., p. 35.

52 __ .Carta a Domício da Gama - 16 de novembro de 1907”. Op. cit., Vol. II, p. 684.

${ }_{53}$ _. “Carta a Francisco Escobar - 12 de fevereiro de 1908". Op. cit., p. 688.

${ }^{54}$ _. .Carta a Oliveira Lima - s/d, jun. de 1909”. Op. cit., p. 708.

${ }^{55}$ _. "Carta a Reinaldo Porchat -26 de agosto de 1892". Op. cit., p. 38.

${ }^{56}$ __ . “Carta a José Veríssimo - 7 de julho de 1907”. Op. cit., p. 647.

${ }^{57}$ __ . “Carta a Coelho Neto - 10 de março de 1905”. Op. cit., p. 661.

${ }^{58}$ __ . “Carta a Oliveira Lima - 28 de junho de 1909”. Op. cit., p. 386.

${ }_{59}^{59}$ __ . “Carta a Otaviano da Costa Vieira - 8 de agosto de 1909”. Op. cit., p. 423.

${ }^{60}$ ELIADE, Mircea. O Sagrado e o Profano. A Essência das Religiões. São Paulo: Martins Fontes, 1992, p. 169.

${ }^{61}$ CASSIRER, Ernst. Ensaio Sobre o Homem. São Paulo: Martins Fontes, 1994, pp. 45-50.

${ }^{62}$ CAMUS, Albert. Le Mythe de Sisyphe. Paris: Gallimard, 1990, p. 37.

Artigo recebido em 04/2002. Aprovado em 09/2002. 